\title{
An investigation on important factors influencing on forecasted earnings adjustment: Evidence from Tehran Stock Exchange
}

\author{
Fatemeh Babakhani $^{a^{*}}$, Behzad Ghorbani ${ }^{\mathrm{b}}$ and Ali Mohammadi ${ }^{\mathrm{a}}$
}

${ }^{a}$ Department of accounting, Science and Research Branch, Islamic Azad University, Zanjan, Iran ${ }^{b}$ Department of Accounting, Khodabandeh Branch, Islamic Azad University, Khodabandeh, Iran

\begin{tabular}{|c|c|}
\hline CHRONICLE & A B S T RACT \\
\hline $\begin{array}{l}\text { Article history: } \\
\text { Received Feb 28, } 2013 \\
\text { Received in revised format } \\
19 \text { September } 2013 \\
\text { Accepted } 23 \text { October } 2013 \\
\text { Available online } \\
\text { November } 282013 \\
\text { Keywords: } \\
\text { Earning forecast } \\
\text { Tehran Stock Exchange }\end{array}$ & $\begin{array}{l}\text { This paper presents an empirical investigation to detect important factors influencing earning } \\
\text { adjustment on firms selected on Tehran Stock Exchange over the period 2006-2011. There are } \\
\text { four independent variables associated with the proposed study of this paper including } \\
\text { Proportion of shares owned by institutional investors, Return on assets, Profit change and } \\
\text { Market value to book value. In addition, Investment restructuring is considered as control } \\
\text { variable. The results of the implementation of regression analysis indicate that there was a } \\
\text { reverse relationship between earning forecasted adjustment and two independent variables } \\
\text { including size of firm as well as the ratio of market value to book value. However, Net profit } \\
\text { has a direct and positive relationship with earning forecast adjustment. }\end{array}$ \\
\hline
\end{tabular}

Size

Market value

Book value

\section{Introduction}

Earnings adjustment is one of the most important concerns among various people including institutional investors, retail investors, etc. (Basu et al., 1998; Baik et al., 2001; Das et al., 2007). There are many studies associated with earnings adjustment. Hirst et al. (2008) provided a framework to view management earnings forecasts and categorized earnings forecasts as having three components - antecedents, characteristics, and consequences - that roughly associated with the timeline of an earnings forecast. They evaluated management earnings forecast and reached three conclusions. First, forecast characteristics seemed to be the least important factor of earnings forecasts even though it was the factor over which managers had had the most control. Second, much of the prior research concentrated on how one prediction antecedent or characteristic influences could forecast consequences and did not study potential interactions among the three components. Third, much of the prior research disregarded the iterative nature of management earnings forecasts.

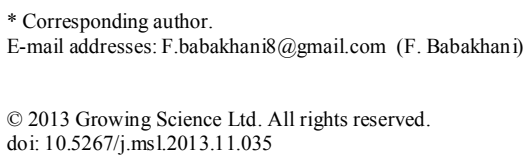


Cordeiro and Kent Jr (2001) re-examined the link between EVA ${ }^{\mathrm{TM}}$ adoption and firm performance, based on security analyst earnings predictions. They started by reviewing some of the literature on EVA $^{\mathrm{TM}}$, stating claims for strengths and weaknesses of that performance measure and management system and then made the case for why security analyst earnings forecasts could be a useful performance measure for testing the performance effects of EVA TM adoption. Cordeiro and Sambharya (1997), in other study performed an empirical investigation to find out about other consequences of corporate reputation and whether corporate reputations could influence security analyst earnings forecasts or not. Jaggi et al. (2006) investigated whether the Taiwanese regulation requiring disclosure of earnings forecasts in the initial public offering (IPOs) yielded in disclosure of more optimistic earnings forecasts and whether the forecast error could be reduced more by manipulating the reported earnings rather than revising the earnings forecasts to reach the forecast error threshold. Their findings indicated that the disclosure regulation resulted in more optimistic forecasts than conservative forecasts, more importantly for firms' expecting better performance in the forecast year compared with the prior year. Chen et al. (2001) performed an investigation on earnings forecast errors in IPO prospectuses and their associations with initial stock returns. Bagnoli et al. (1999) investigated about the effects of whisper forecasts of quarterly earnings per share.

\section{The proposed model}

This paper presents an empirical investigation to study important factors influencing earning adjustment on firms selected on Tehran Stock Exchange over the period 2006-2011. There are five main hypotheses with the proposed study of this paper as follows,

1. The size (SIZE) of a firm influences on forecasted earning adjustment (ACCURACY).

2. The return of assets (ROA) influences on forecasted earning adjustment.

3. The proportion of shares owned by institutional investors (INST) influences on forecasted earning adjustment.

4. Net profit change (EARNVOL) influences on forecasted earning adjustment.

5. The ratio of market value on book value (MB) influences on forecasted earning adjustment.

In our survey, we consider standard deviation of a three years net earnings as Net profit change (EARNVOL).

There are four independent variables associated with the proposed study of this paper including Proportion of shares owned by institutional investors, Return on assets, Profit change and Market value to book value. In addition, Investment restructuring is considered as control variable. The selection of sample size from Tehran Stock Exchange is based on the following criteria,

1. They all must have the same fiscal year ending March.

2. All accepted firms must have been listed on stock exchange prior to year 2005 .

3. No investment or holding firm is allowed in this study.

4. All financial information must be available.

5. There must be no long trade interruption on any accepted firm (Not more than four months).

After performing a comprehensive survey, we have ended up having 103 firms. The following is the regression model to verify the hypotheses of the study,

$A C C U R A C Y=\beta_{0}+\beta_{1} S I Z E+\beta_{2} R O A+\beta_{3} I N S T+\beta_{4} E A R N V O L+\beta_{5} M B+\beta_{6} R E S T R A C T U R E+\varepsilon$. 
We first present details of some basic statistics on the data. Table 1 shows the summary of mean, standard deviation of the data.

\section{Table 1}

The summary of basic statistics

\begin{tabular}{lcccc}
\hline Symbol & Min & Max & Mean & Standard deviation \\
\hline ACCURACY & 0 & 3.1573 & 0.131418 & 0.304133 \\
Size & 9.0597 & 18.5655 & 12.9806 & 1.598663 \\
ROA & -0.7179 & 0.6274 & 0.111105 & 0.137618 \\
MB & -18.1829 & 37.7659 & 2.68786 & 4.072065 \\
INST & 0 & 0.9923 & 0.308944 & 0.26957 \\
EARNVOL & 0.0005 & 0.5119 & 0.049118 & 0.058577 \\
RESTRUCTURE & 0 & 1 & 0.36 & 0.01287 \\
\hline
\end{tabular}

For the implementation of the survey, we have used Husman test to learn whether we should choose random or fixed effect and the results of our survey has indicated that fixed effect method is an appropriate method for regression analysis.

\section{The results}

In this section, we present details of our findings on testing various hypotheses of the survey. Table 2 shows details of our findings.

Table 2

The results of regression analysis

\begin{tabular}{lccccc}
\multicolumn{1}{c}{ Symbol } & \multirow{2}{*}{$*$} & \multirow{2}{*}{ t-student } & P-value & \multicolumn{2}{c}{ Co-linearity test } \\
\cline { 4 - 6 } Size & -0.027 & -2.372 & 0.018 & Tolerance & Inflated variance \\
ROA & -0.184 & -1.522 & 0.128 & 0.865 & 1.156 \\
INST & 0.093 & 1.68 & 0.092 & 0.902 & 1.092 \\
EARNVOL & 1.66 & 6.55 & 0.00 & 0.811 & 1.258 \\
MB & -0.008 & -2.015 & 0.044 & 0.923 & 1.007 \\
RESTRACTURE & 0.001 & 0.046 & 0.962 & 0.902 & 1.456 \\
\hline Durbin-Watson $=1.615$, F-value $=28.265$ Sig. $=0.000$, F-Limer $=2.847$ Sig. $=0.006$, Chi-Square $=10.14$, S-g. $=0.071, \mathrm{R}^{2}=0.271$
\end{tabular}

As we can observe from the results of Table 2, the coefficients of Size, EARNVOL and MB are statistically significance. Durbin-Watson value is within acceptable limit, which means there is no autocorrelation among the residuals, F-value is equal to 28.265 with Sig. $=0.000$, which means the relationship is linear. Adjusted R-Square is equal to 0.271 , which means the regression analysis could describe approximately 27 percent of the changes on dependent variable.

\subsection{The first hypothesis: The effect of Size}

The first hypothesis is associated with the effect of Size on forecasted earnings adjustment. According to the results of Table 2, the coefficient associated with Size is equal to -0.027 , which is statistically meaningful when the level of significance is one percent. Therefore, the first hypothesis of this survey has been confirmed.

\subsection{The second hypothesis: The effect of ROA}

The second hypothesis is associated with the effect of ROA on forecasted earnings adjustment. According to the results of Table 2, the coefficient associated with ROA is not significance. Therefore, the second hypothesis of this survey has not been confirmed. 


\subsection{The third hypothesis: The effect of institutional investors (INST)}

The third hypothesis is associated with the effect of institutional investors on forecasted earnings adjustment. According to the results of Table 2, the coefficient associated with Size is equal to 0.093, which is statistically meaningful when the level of significance is only ten percent. Therefore, the first hypothesis of this survey has been confirmed.

\subsection{The fourth hypothesis: The effect of Net profit change (EARNVOL)}

The fourth hypothesis is associated with the effect of Net profit change on forecasted earnings adjustment. According to the results of Table 2, the coefficient associated with Net profit is equal to 1.66 , which is statistically meaningful when the level of significance is one percent. Therefore, the first hypothesis of this survey has been confirmed.

\subsection{The fifth hypothesis: The effect of market value on book value (MB)}

The fifth hypothesis is associated with the effect of market value on book value (MB) on forecasted earnings adjustment. According to the results of Table 2, the coefficient associated with MB is not significance. Therefore, the fifth hypothesis of this survey has not been confirmed.

\section{Conclusion}

One of the primary concerns on any stock exchange is to find out more about the factors influencing accuracy of earning on stock exchange. In this paper, we have presented an empirical investigation to find out about the effects of five variables of size, return on assets, institutional investors, net profit change and market value on book value. The results of the implementation of regression analysis indicate that there is reverse relationship between earning forecasted adjustment and two independent variables including size of firm as well as the ratio of market value to book value. However, Net profit has had a direct and positive relationship with earning forecast adjustment.

\section{References}

Basu, S., Hwang, L., \& Jan, C. L. (1998). International variation in accounting measurement rules and analysts' earnings forecast errors. Journal of Business Finance \& Accounting, 25(9-10), 1207 1247.

Baik, B. O. K., Farber, D. B., \& LEE, S. S. (2011). CEO Ability and Management Earnings Forecasts*. Contemporary Accounting Research, 28(5), 1645-1668.

Bagnoli, M., Beneish, M. D., \& Watts, S. G. (1999). Whisper forecasts of quarterly earnings per share. Journal of Accounting and Economics, 28(1), 27-50.

Chen, G., Firth, M., \& Krishnan, G. V. (2001). Earnings forecast errors in IPO prospectuses and their associations with initial stock returns. Journal of Multinational Financial Management, 11(2), 225-240.

Cordeiro, J. J., \& Sambharya, R. B. (1997). Part V: Other consequences of corporate reputation: Do corporate reputations influence security analyst earnings forecasts? An empirical study. Corporate Reputation Review, 1(2), 94-98.

Cordeiro, J. J., \& Kent Jr, D. D. (2001). Do EVA ${ }^{\mathrm{TM}}$ Adopters Outperform their Industry Peers? Evidence from Security Analyst Earnings Forecasts. American Business Review, Paper 12.

Das, S., Kim, K., \& Patro, S. (2007). Management Earnings Forecasts and Subsequent Price Formation. Working Paper, University of Illinois-Chicago.

Jaggi, B., Chin, C. L., Lin, H. W. W., \& Lee, P. (2006). Earnings forecast disclosure regulation and earnings management: evidence from Taiwan IPO firms. Review of Quantitative Finance and Accounting, 26(3), 275-299.

Hirst, D. E., Koonce, L., \& Venkataraman, S. (2008). Management earnings forecasts: A review and framework. Accounting Horizons, 22(3), 315-338. 